\title{
IMPLEMENTASI QUALITY OF SERVICE, LIMIT BANDWIDTH DAN LOAD BALANCING DENGAN MENGGUNAKAN FIRMWARE DD-WRT PADA ROUTER BUFFALO WHR-HP-G300N
}

\author{
Januardi nasir \\ Fakultas Teknik dan Komputer, Program Studi Teknik Informatika \\ Universitas Putera Batam \\ Email: januardinasir@gmail.com \\ Eric Andrianto \\ Program Studi Teknik Informatika \\ Universitas Putera Batam \\ Email: eric_andrianto@outlook.com
}

\begin{abstract}
ABSTRAK
Internet di era sekarang menjadi sebuah keharusan dalam melakukan segala hal. Begitu pula di PT. LFC Teknologi Indonesia, semua kegiatan diperlukan akses internet, baik dari pengaksesan database, berkomunikasi antar konsumen dan supplier melalui aplikasi chat dan e-mail. Pada penelitian ini akan dilakukan optimalisasi jaringan internet dengan mengimplementasikan Quality of Service, Limit Bandwidth dan Load Balancing menggunakan firmware DD-WRT pada router Buffalo WHR-HPG300N. Hasil pengukuran akan diolah untuk dianalisis nilai throughput, delay, packet loss, jitter, latency dan bandwidth guna untuk mengetahui kualitas jaringan internet sebelum dan sesudah optimalisasi serta ditampilkan dalam bentuk tabel beserta grafik perbandingan dan dibagi dalam dua (2) tahapan analisis. Dari hasil penelitian dapat disimpulkan bahwa jaringan sesudah optimalisasi lebih stabil, cepat dan optimal dengan nilai throughput, delay, jitter, latency dan packet loss terendah. Sedangkan nilai kecepatan bandwidth sesudah optimalisasi mengalami kenaikan.
\end{abstract}

Kata kunci: quality of service, limit bandwidth, load balancing, DD-WRT, router buffalo.

\begin{abstract}
Internet in the current era becomes a necessity in doing everything. As well as in PT. LFC Teknologi Indonesia, all activities required internet access, either from accessing the database, communicating between consumers and suppliers through chat and e-mail application. This research will be carried out to optimize the Internet by implementing Quality of Service, Bandwidth Limit and Load Balancing using DD-WRT firmware on Buffalo router WHR-HP-G300N. The results of measurement will be processed to analyze the value of throughput, delay, packet loss, jitter, latency and bandwidth in order to know the quality of internet network before and after optimization. The results will also presented in form of tables along with comparison graph and divided in two (2) analysis phase. From the results of the research can be concluded that the network after optimization is more stable, fast and optimal with the lowest throughput, delay, jitter, latency and packet loss. While the value of the bandwidth speed increased after optimization.
\end{abstract}

Keywords: quality of service, limit bandwidth, load balancing, DD-WRT, router buffalo.

\section{PENDAHULUAN}

Berdasarkan data dari International Telecommunication Union [1], menyatakan bahwa terhitung sampai bulan Juli tahun 2017, total pengguna internet di dunia telah mencapai $48 \%$ dari total seluruh penduduk di dunia. Dengan bertambahnya pengguna internet setiap harinya, maka kebutuhan akan bandwidth pun semakin tinggi. Untuk organisasi besar atau perusahaan seperti PT. LFC Teknologi Indonesia sangat membutuhkan bandwidth yang besar untuk melancarkan proses kerjanya.

PT. LFC Teknologi Indonesia merupakan sebuah perusahaan PMA yang bergerak dibidang distribusi, pemeliharaan dan penyedia solusi di bidang metrologi, pemotongan, laser dan mesin industri berat. PT. LFC Teknologi Indonesia juga bekerja sama dengan sejumlah principal yang berasal dari berbagai negara seperti Jepang, Italia, Jerman, Belanda, Taiwan, China dan lain-lain. Tentunya untuk berkomunikasi jarak jauh dengan principal membutuhkan komunikasi antar e-mail, video call, maupun di 
remote dengan teamviewer secara langsung. Maka itu, dibutuhkan koneksi internet untuk melancarkan semua proses komunikasi baik antar principal maupun antar pelanggan.

Masalah yang sering terjadi di PT. LFC Teknologi Indonesia ialah ketika berkomunikasi dengan principal menggunakan video call, sering terjadi lag dan packet loss. Hal ini disebabkan karena pengalokasian bandwidth yang tidak maksimal. Selain itu, bandwidth yang tersedia juga terbatas sehingga terjadi saling tarik-menarik bandwidth antar sesama pengguna yang berada didalam suatu jaringan tersebut. Faktor ini dikarenakan bertambah banyaknya pengguna pada suatu jaringan tersebut, maka bandwidth yang ada terbagi ke semua pengguna sekaligus. Setelah ditelusuri, tenyata terdapat beberapa cara sebagai solusi yang dapat mengoptimalkan bandwidth yang dimiliki mencapai kinerja maksimal sehingga tidak sering terjadi delay, packet loss dan jitter dalam pemakaian internet.

Solusi yang disarankan ialah dengan menerapkan Quality of Service, Limit Bandwidth dan Load Balancing untuk memprioritaskan dan menstabilkan jaringan internet saat dipakai untuk berbagai aktifitas secara bersamaan, memanajemen bandwidth per user sehingga bandwidth yang tersedia cukup dan pada saat ISP utama terdapat gangguan, jaringan internet dapat menggunakan ISP cadangan sehingga tidak menyebabkan gangguan pada pengguna pada saat melakukan pekerjaan.

\subsection{Quality Of Service}

Quality of Service $(Q \circ S)$ adalah teknik untuk mengelola bandwidth, delay, jitter, dan packet loss untuk aliran dalam jaringan [2]. Quality of Service (QoS) juga menempatkan beberapa batasan dalam bentuk kendala tertentu dalam perjalanan jaringan. Kendala ini meliputi bandwidth yang diinginkan, delay, variasi delay yang dialami oleh penerima (jitter), packet loss yang dapat ditoleransi, tidak ada loncatan dan biaya jaringan [3]. Quality of Service juga merupakan kemampuan elemen jaringan (misalnya aplikasi, host atau router) untuk memiliki beberapa tingkat jaminan bahwa persyaratan lalu lintas dan layanan akan terpenuhi [4].

Skema Quality of Service merupakan antrian menyediakan layanan jaringan yang dapat diprediksi dengan menyediakan bandwidth khusus, jitter dan latency terkontrol, dan karakteristik packet loss yang lebih baik. Ide dasarnya adalah mengalokasikan sumber daya (ruang processor, memori $R A M$ ) terlebih dahulu untuk data sensitif [5].

Kemampuan Quality of Service mengacu pada tingkat kecepatan dan kehandalan penyampaian berbagai jenis beban data di dalam suatu komunikasi. Kemampuannya merupakan kumpulan dari beberapa parameter besaran teknis, yaitu [6]:

a. Throughput yaitu kecepatan (rate) transfer data efektif, yang diukur dalam bit/s. Throughput merupakan jumlah total kedatangan paket yang sukses yang diamati pada destinasi selama interval waktu tertentu dibagi oleh durasi interval waktu tersebut.

b. Delay adalah waktu tunda suatu paket yang diakibatkan oleh proses transmisi dari satu titik ke titik lain yang menjadi tujuannya.

c. Jitter merupakan variasi dari delay end-to-end. Level yang tinggi pada jitter dalam aplikasi berbasis User Datagram Protocol (UDP) merupakan situasi yang tidak dapat diterima dimana aplikasi merupakan aplikasi real time, seperti sinyal audio dan video. Pada kasus seperti itu, jitter akan menyebabkan sinyal terdistorsi, yang dapat diperbaiki hanya dengan meningkatkan buffer di antrian.

d. Packet loss didefinisikan sebagai kegagalan transmisi paket IP mencapai tujuannya. Kegagalan paket tersebut untuk mencapai tujuan dapat disebabkan oleh beberapa kemungkinan yaitu terjadinya overload trafik didalam jaringan, tabrakan (congestion) dalam jaringan, error yang terjadi pada media fisik, kegagalan yang terjadi pada sisi penerima antara lain bisa disebabkan karena overflow yang terjadi pada buffer.

\subsection{Load Balancing Jaringan}

Load balancing adalah teknik untuk mendistribusikan beban trafik pada dua atau lebih jalur koneksi secara seimbang, agar trafik dapat berjalan optimal, memaksimalkan throughput, memperkecil waktu tanggap dan menghindari overload pada salah satu jalur koneksi. Load balancing digunakan pada saat sebuah server telah memiliki jumlah user yang telah melebihi maksimal kapasitasnya [7].

Teknik yang mendistribusikan kelebihan beban kerja lokal yang dinamis secara merata di semua simpul merupakan dan berfokus pada throughput maksimum, menghindari overloading dan mengurangi konsumsi energi dengan mendistribusikan beban secara merata, meminimalkan waktu respon dan mengurangi latensi jaringan [8]. Load Balancing berguna untuk membagi beban jaringan (traffic) melalui beberapa link network yang tersedia untuk meningkatkan throughput, mengurangi response time maupun 
menghindari penumpukan trafik yang berlebihan. Teknik load balancing dapat diterapkan jika router memiliki beberapa link untuk mencapai suatu network tujuan [9].

Cara kerja load balancing ialah dengan menggunakan beberapa peralatan yang sama untuk menjalankan tugas yang sama. Hal ini memungkinkan pekerjaan dilakukan dengan lebih cepat dibandingkan apabila hanya dikerjakan oleh 1 (satu) peralatan saja dan dapat meringankan beban kerja peralatan, serta mempercepat waktu respon. Load Balancer bertindak sebagai penengah di antara layanan utama dan pengguna, dimana layanan utama merupakan sekumpulan server atau mesin yang siap melayani banyak pengguna. Keuntungan yang diperoleh dari penerapan load balancing sebagai berikut [10]:

a. Waktu Respon

Meningkatkan kecepatan akses website saat dibuka. Dengan dua atau lebih server yang saling berbagi beban lalu lintas web, masing-masing akan berjalan lebih cepat karena beban tidak berada pada 1 (satu) server saja. Ini berarti ada lebih banyak sumber daya untuk memenuhi permintaan halaman website..

b. Redundansi

Dengan load balancing, akan mewarisi sedikit redundansi. Sebagai contoh, jika website kita berjalan seimbang di 3 (tiga) server dan salah satu server bermasalah, maka dua server lainnya dapat terus berjalan dan pengunjung website kita tidak akan menyadari downtime apapun.

\subsection{Limit Bandwidth}

Bandwidth adalah besaran untuk menunjukkan seberapa banyak data yang dapat dilewatkan dalam koneksi melalui sebuah network. Bandwidth disebut juga lebar pita atau kapasitas saluran informasi yaitu kemampuan maksimum dari suatu alat untuk menyalurkan informasi dalam satuan waktu detik [11]. Bandwidth mengacu pada jumlah informasi yang dapat dikirim pada waktu tertentu sepanjang jalur data. Secara umum, bandwidth jaringan adalah ukuran bit rate dari sumber komunikasi data yang tersedia atau yang dikonsumsi yang dinyatakan dalam bit per second atau kelipatannya yaitu kilobit per second, megabits per second dan lain-lain [12].

Manajemen bandwidth juga merupakan seperangkat teknik dan alat yang ditujukan untuk mengurangi segmen kritis dalam jaringan yang mencakup kompresi data, prioritas bandwidth berdasarkan kriteria tertentu, pemblokiran, pembentukan lalu lintas, pengendalian lalu lintas, dan lain-lain. Tujuan pengelolaan bandwidth adalah untuk mengoptimalkan kinerja jaringan agar bisa diamankan. Di dalam dunia internet sering di dengar istilah limiter atau pembatasan kecepatan untuk melakukan akses ke internet. Ada beberapa jenis sistem limiter yang biasa diaplikasikan ke router, mulai dari yang simple hingga yang kompleks [13].

\subsection{Tools Dan Software Pendukung}

Untuk penelitian optimalisasi jaringan dengan penerapan quality of service, limit bandwidth dan load balancing dibutuhkan tools dan software sebagai berikut :
a. Wireless Router Buffalo WHR-HP-G300N dan Asus RT-N15U dengan firmware DD-WRT V24
b. Kabel UTP Cat $5 e$ dan head RJ-45
c. Laptop atau PC yang bisa menjalankan aplikasi web browser (Google Chrome, Mozilla Firefox)
d. Internet dari Internet Service Provider (ISP) dan hotspot (mobile hotspot, MiFi dan sejenisnya)
e. Aplikasi Axence NetTools, NetWorx dan Internet Download Manager
f. Aplikasi website speedtest.net, info.onsip.com dan sourceforget.net

\subsection{Kerangka Pemikiran}

Seperti halnya dengan alat pengambilan data, rancangan penelitian juga didiktekan oleh variabelvariabel penelitian yang telah diidentifikasi serta oleh hipotesis yang akan diuji kebenarannya. Dalam menentukan rancangan penelitian yang mana akan digunakan, perlu sekali selalu diingat bahwa seluruh komponen penelitian itu harus terjalin secara serasi dan tertib [14].

Berdasarkan teori-teori yang telah diperoleh dan dijelaskan, maka kerangka berpikir dari penelitian, digambarkan pada kerangka pemikiran yang disajikan pada gambar di bawah ini. 


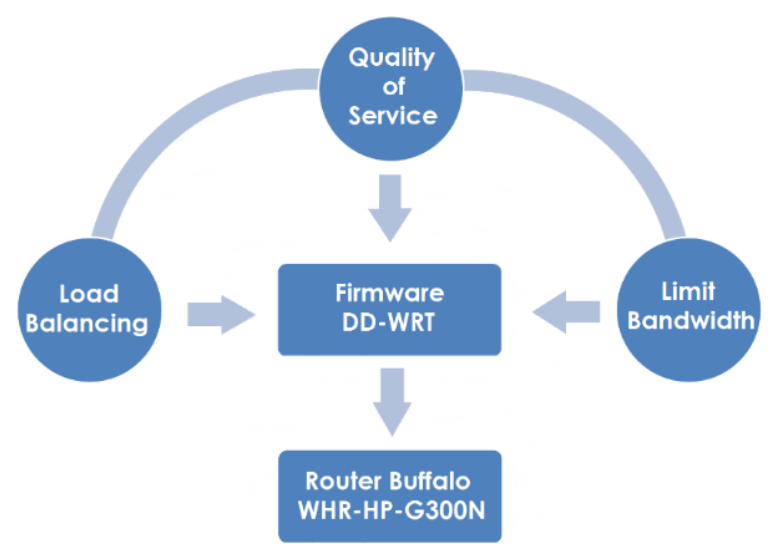

Gambar 1. Kerangka Pemikiran

\section{METODOLOGI PENELITIAN}

\subsection{Desain Penelitian}

Desain penelitian dapat diartikan sebagai cara ilmiah untuk mendapatkan data yang valid dengan tujuan dapat ditemukan, dikembangkan, dan dibuktikan, suatu pengetahuan tertentu sehingga pada gilirannya dapat digunakan untuk memahami, memecahkan dan mengantisispasi masalah [15]. Desain penelitian memberikan prosedur untuk mendapatkan informasi yang diperlukan untuk menyusun atau menyelesaikan masalah dalam penelitian. Oleh sebab itu, desain penelitian yang baik dibagi menjadi dua tipe yaitu, eksploratif dan konklusif. Desain penelitian konklusif dibagi lagi menjadi dua tipe yaitu deskriptif dan kausal. Penelitian deskriptif memiliki pernyataan yang jelas mengenai permasalahan yang dihadapi, hipotesis yang spesifik, dan informasi detail yang dibutuhkan. Adapun rancangan penelitian dapat dilihat pada gambar dibawah ini.

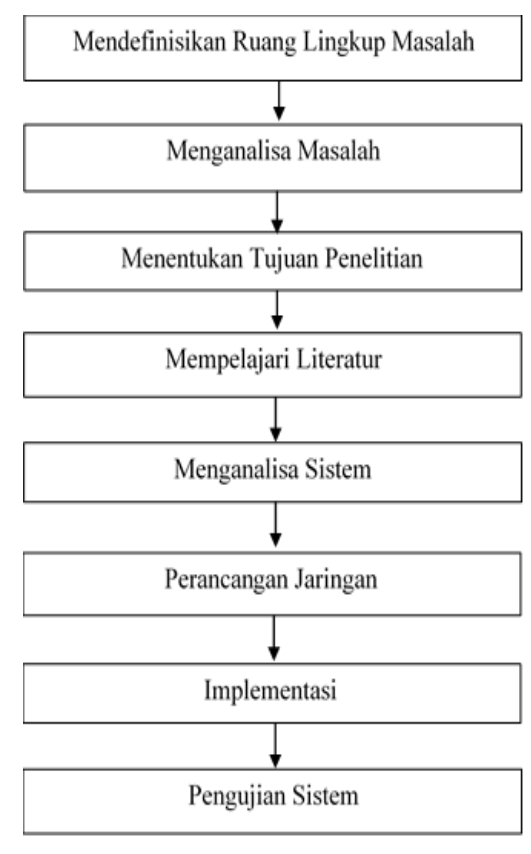

Gambar 2. Desain Penelitian

\subsection{Operasional Variabel}

Variabel penelitian adalah segala sesuatu yang berbentuk apa saja yang ditetapkan oleh peneliti untuk dipelajari sehingga diperoleh informasi tentang hal tersebut, kemudian ditarik kesimpulan. Variabel yang digunakan dalam penelitian dapat diklasifikasikan menjadi dua yaitu variabel independen (bebas) dan variabel dependen (terikat). Variabel independen yaitu variabel yang menjelaskan dan memengaruhi 
variabel lain, dan variabel dependen yaitu variabel yang dijelaskan dan dipengaruhi oleh variabel independen [16]. Variabel dependen dalam penelitian ini dapat dilihat dalam tabel dibawah ini.

Tabel 4. Definisi operasional variabel dependen

\begin{tabular}{clcc}
\hline Variabel & \multicolumn{1}{c}{ Indikator } & Satuan $($ Monitoring) & Skala (Statistik) \\
\hline \multirow{5}{*}{ Akses Data } & Bandwidth Speed & $\mathrm{Kb} / \mathrm{s}$ & Ordinal \\
& Data Traffic & $\mathrm{Mb} / \mathrm{s}$ & Ordinal \\
& Throughput & $\mathrm{Kb} / \mathrm{s}$ & Ordinal \\
& Delay & $\mathrm{ms}$ & Ordinal \\
& Jitter & $\mathrm{ms}$ & Ordinal \\
& Latency & $\mathrm{ms}$ & Ordinal \\
& Packet Loss & $\%$ & Ordinal \\
\hline
\end{tabular}

\subsection{Object Monitoring}

Object monitoring dalam penelitian ini adalah segala sesuatu yang akan dijadikan subjek atau objek penelitian yang dikehendaki peneliti. Maka yang akan dijadikan objek dalam melakukan penelitian ini seperti gambar dibawah ini dengan menampilkan proses implementasi dari dua ISP yang dikoneksikan ke dua modem internet dan digabungkan ke wireless router Buffalo WHR-HP-G300N dengan mengaktifkan fitur Quality of Service, Limit Bandwidth dan Load Balancing. Host seperti PC, Smartphone dan Laptop terhubung ke jaringan melalui kabel $L A N$ atau Wi-Fi.

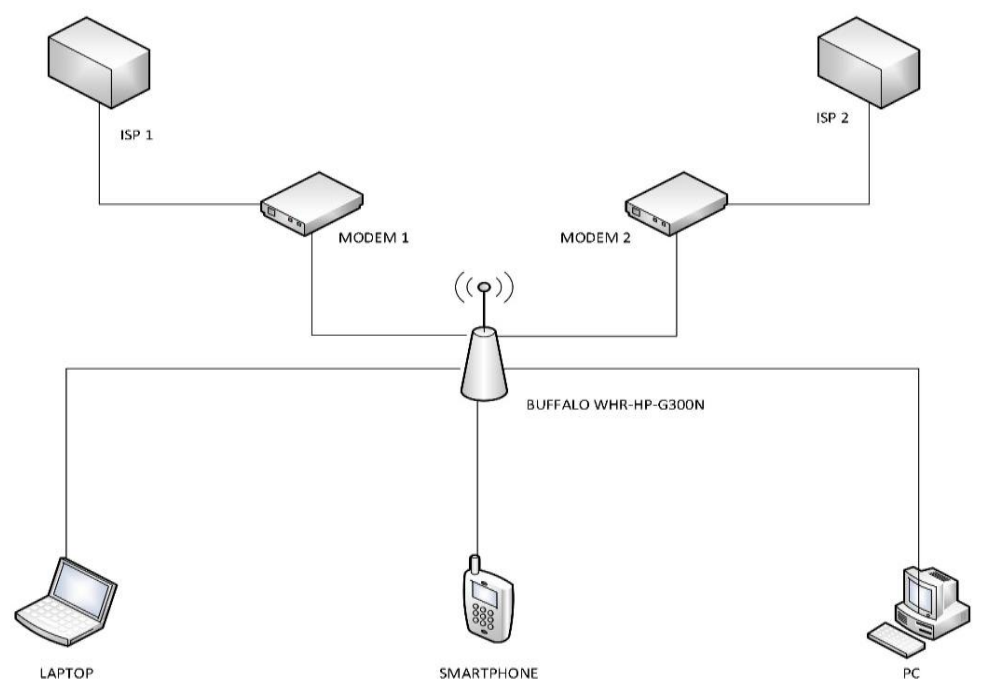

Gambar 3. Object Monitoring Jaringan Internet PT. LFC Teknologi Indonesia

\section{HASIL DAN PEMBAHASAN}

\subsection{Analisis Deskriptif}

Pengukuran Quality of Service, Limit Bandwidth dan Load Balancing pada jaringan internet di PT. LFC Teknologi Indonesia dipantau secara bertahap dalam jangka waktu 4 (empat) hari, terhitung dari tanggal 6 dan 7 Januari 2018 sebagai tahap 1 (satu) sebelum melakukan implementasi dan tanggal 13 dan 14 Januari 2018 sebagai tahap 2 (dua) setelah melakukan implementasi. Untuk mengimplementasikan rencana yang telah disusun, maka model dari sistem traffic monitoring network dan parameter Quality of Service yang digunakan untuk pengukuran kualitas jaringan internet adalah bandwidth, throughput, delay, jitter, latency dan packet loss. Sedangkan untuk Limit Bandwidth parameternya merupakan bandwidth download dengan kondisi pada saat mengunduh file secara bersamaan dengan 3 user atau lebih. Ping dan request timeout (RTO) merupakan parameter untuk pengukuran kualitas jaringan pada saat diterapkan load balancing. Hasil dari pengukuran akan di paparkan dalam bentuk analisis deskriptif yang hasil pengukurannya diperoleh dari aplikasi NetWorx, Axence NetTools, Internet Download Manager dan aplikasi website dari speedtest.net, sourceforge.net dan info.onsip.com. 


\subsection{Analisis Kecepatan Traffic Jaringan}

\subsubsection{Analisis Kecepatan Traffic Jaringan Tahap 1}

Berdasarkan hasil analisis kecepatan traffic jaringan tahap 1 dapat dijelaskan bahwa kecepatan ratarata internet Wi-Fi di PT. LFC Teknologi Indonesia yang di ukur dengan aplikasi Speedtest sebesar 30650 kbps untuk download, sedangkan untuk upload memiliki kecepatan sebesar 18540 kbps, dari hasil pengamatan atau pengukuran ini dapat disimpulkan bahwa pengukuran dengan menggunakan aplikasi Speedtest dapat memperlihatkan kecepatan internet pada koneksi internet di PT. LFC Teknologi Indonesia. Untuk hasil pengukurannya dapat dilihat dari grafik berikut:

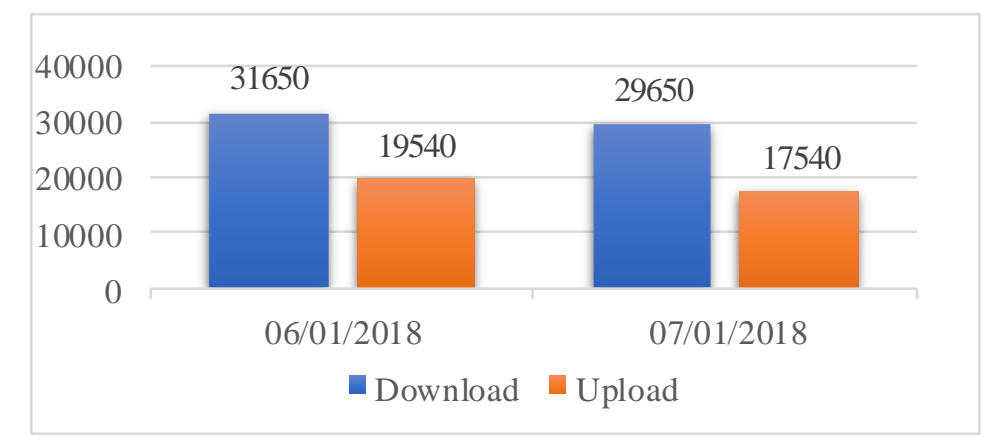

Gambar 4. Grafik Pengukuran Kecepatan Internet Tahap 1

\subsubsection{Analisis Kecepatan Traffic Jaringan Tahap 2}

Berdasarkan hasil analisis kecepatan traffic jaringan tahap 2 dapat dijelaskan bahwa kecepatan ratarata internet Wi-Fi di PT. LFC Teknologi Indonesia sesudah diimplementasi Quality of Service, Limit Bandwidth dan Load Balancing yang di ukur dengan aplikasi Speedtest sebesar 95190 kbps untuk download, sedangkan untuk upload memiliki kecepatan sebesar $16980 \mathrm{kbps}$. Dari hasil pengamatan atau pengukuran ini dapat disimpulkan bahwa pengukuran dengan menggunakan aplikasi Speedtest dapat memperlihatkan kecepatan internet di PT. LFC Teknologi Indonesia yang sesudah diimplementasi Quality of Service, Limit Bandwidth dan Load Balancing. Untuk hasil pengukurannya dapat dilihat dari grafik berikut:

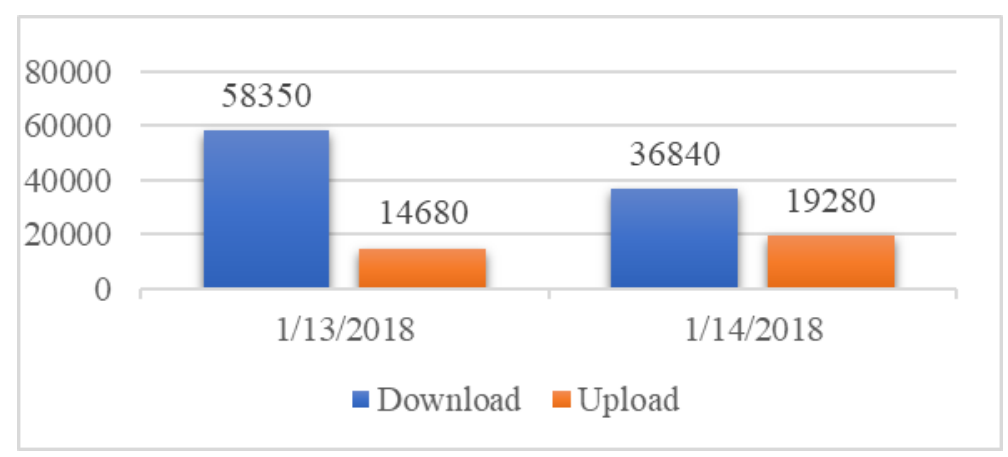

Gambar 5. Grafik Pengukuran Kecepatan Internet Tahap Dua

\subsection{Analisis Quality of Service (QoS) dengan Axence NetTools}

Pengukuran Quality of Service dilakukan dengan cara mencoba alamat website pada alat ukur yang digunakan yaitu Axence NetTools. Alamat website yang dijadikan percobaan ada empat website yang kemudian dijadikan percobaan dalam monitoring Quality of Service. Diantaranya adalah www.lfc.co.id, www.lfc.com.sg, www.yakinmaju.com dan server.lfc.local. Keempat website tersebut digunakan untuk mengukur nilai throughput, delay, latency dan jitter.

\subsubsection{Analisis Pengukuran Nilai Throughput}

Pada saat transmisi data yang telah dimonitoring oleh Axence NetTools dan di-capture, maka hasil throughput adalah bits per second. Peneliti merubah satuan bits per second ke kilo bits per second. 
Setelah mengetahui kecepatan throughput, maka peneliti menganalisis kecepatan yang dibutuhkan dalam satu paket dalam setiap website hingga data diterima. Dapat dilihat hasil analisis throughput menunjukkan bahwa tahap 1 yaitu jaringan internet di PT. LFC Teknologi Indonesia yang sebelum diimplementasi memiliki throughput paling tinggi yaitu mencapai 6808,77 Kbit/s. Sedangkan di tahap 2 yang sesudah diimplementasi mencapai maksimal throughput 6666,51 Kbit/s.

Tabel 5. Hasil pengukuran throughput

\begin{tabular}{clccc}
\hline $\begin{array}{c}\text { Tahapan } \\
\text { Analisis }\end{array}$ & \multicolumn{1}{c}{ Website } & Max (Kbit/s) & $\begin{array}{c}\text { Throughput } \\
\text { Min }(\text { Kbit/s) }\end{array}$ & Avg (Kbit/s) \\
\hline \multirow{3}{*}{1} & 192.168.1.200 & 6808,77 & 91,87 & 4431,32 \\
& www.lfc.com.sg & 3609,8 & 26,58 & 2502,34 \\
& www.lfc.co.id & 3533,46 & 72,29 & 2601,82 \\
& www.yakinmaju.com & 3617,76 & 70,95 & 2531,38 \\
& 192.168.1.200 & 6666,51 & 23,7 & 4281,62 \\
& www.lfc.com.sg & 3602,72 & 22,3 & 2211,25 \\
& www.lfc.co.id & 3289,11 & 25,10 & 2144,74 \\
& www.yakinmaju.com & 3276,21 & 186,3 & 2602,8 \\
\hline
\end{tabular}

\subsubsection{Analisis Pengukuran Nilai Delay}

Delay dalam penelitian ini merupakan waktu yang dibutuhkan saat transmisi data yang berupa paket untuk mencapai komputer yang dituju dalam satuan milisecond (ms). Hasil pengukuran delay dapat disimpulkan bahwa yang memiliki delay tertinggi adalah pada saat koneksi jaringan di tahap 1 (sebelum diimplementasi), dengan rata-rata waktu delay sebesar $23 \mathrm{~ms}$ pada saat koneksi ke www.lfc.com.sg, www.lfc.co.id, www.yakinmaju.com dan rata-rata delay $18 \mathrm{~ms}$ pada server.lfc.local. Sedangkan di tahap 2, rata-rata waktu delay pada saat koneksi ke www.lfc.com.sg, www.lfc.co.id dan www.yakinmaju.com sebesar $13 \mathrm{~ms}$ dan $10 \mathrm{~ms}$ pada server.lfc.local.

Tabel 6. Hasil pengukuran delay

\begin{tabular}{|c|c|c|c|c|}
\hline \multirow{2}{*}{ Tahapan Analisis } & \multirow{2}{*}{ Website } & \multicolumn{3}{|c|}{ Delay (ms) } \\
\hline & & $\operatorname{Max}$ & Min & Avg \\
\hline \multirow{4}{*}{1} & 192.168.1.200 (server.lfc.local) & 953 & 2 & 18 \\
\hline & www.lfc.com.sg & 811 & 5 & 23 \\
\hline & $w w w . l f c . c o . i d$ & 976 & 5 & 23 \\
\hline & www.yakinmaju.com & 997 & 5 & 23 \\
\hline \multirow{4}{*}{2} & 192.168.1.200 (server.lfc.local) & 266 & 2 & 10 \\
\hline & www.lfc.com.sg & 276 & 5 & 13 \\
\hline & $w w w . l f c . c o . i d$ & 279 & 5 & 13 \\
\hline & www.yakinmaju.com & 286 & 5 & 13 \\
\hline
\end{tabular}

\subsubsection{Analisis Pengukuran Nilai Packet Loss}

Packet loss dalam penelititan ini merupakan paket data yang terbuang atau paket yang tidak sampai pada tujuan. Data packet loss juga diambil dari pengukuran perintah ping yang menggunakan software Axence NetTools. Paket yang tidak sampai tersebut akan dihitung dan dicari jumlah dalam persentase (\%). Untuk menganalisa parameter packet loss, data dihitung dari > 1000 paket yang dikirim dengan menggunakan perintah ping dalam aplikasi Axence NetTools. Kemudian jumlah paket yang tidak sampai tujuan akan dihitung dalam persentase (\%). Hasil pengukuran packet loss dapat disimpulkan bahwa yang memiliki paket loss tertinggi ialah pada tahap 1 yang sebelum diimplementasi dengan jumlah Packet loss $>20$ paket dengan persentase mencapai $2 \%$, sedangkan pada tahap 2 yang sesudah diimplementasi dengan jumlah Packet Loss 0 paket dan persentase $<=0 \%$. 
Tabel 7. Hasil pengukuran packet loss

\begin{tabular}{clcccc}
\hline $\begin{array}{c}\text { Tahapan } \\
\text { Analisis }\end{array}$ & \multicolumn{1}{c}{ Website } & \multicolumn{3}{c}{ Packet Loss (kbps) } \\
\hline \multirow{3}{*}{1} & 192.168.1.200 (server.lfc.local) & 991 & 811 & 18 & 2 \\
& www.lfc.com.sg & 877 & 858 & 19 & 2 \\
& www.lfc.co.id & 979 & 959 & 20 & 2 \\
& www.yakinmaju.com & 956 & 936 & 20 & 2 \\
& 192.l68.1.200 (server.lfc.local) & 911 & 911 & 0 & 0 \\
2 & www.lfc.com.sg & 872 & 872 & 0 & 0 \\
& www.lfc.co.id & 920 & 920 & 0 & 0 \\
& www.yakinmaju.com & 926 & 926 & 0 & 0 \\
\hline
\end{tabular}

\subsubsection{Analisis Pengukuran Nilai Latency}

Latency dalam penelitian ini adalah jumlah waktu yang dibutuhkan paket data untuk berpindah di seluruh koneksi jaringan dalam satuan mili second (ms). Perhitungan data Latency diukur dengan aplikasi website info.onsip.com/voip-test dan sourceforge.net/speedtest. Dari tabel tersebut dapat disimpulkan bahwa yang memiliki latency tertinggi adalah pada tahapan analisis ke 1 dengan latency 299 ms diuji dengan aplikasi website info.onsip.com dan $64 \mathrm{~ms}$ pada aplikasi website sourceforge.net. Sedangkan pada tahapan analisis ke 2 memiliki hasil latency $243 \mathrm{~ms}$ pada website info.onsip.com dan $48 \mathrm{~ms}$ latency pada website sourceforge.net

Tabel 8. Hasil pengukuran latency

\begin{tabular}{ccc}
\hline Tahapan Analisis & Website & Latency (ms) \\
\hline \multirow{2}{*}{1} & info.onsip.com & 299 \\
& sourceforge.net & 64 \\
2 & info.onsip.com & 243 \\
& sourceforge.net & 48 \\
\hline
\end{tabular}

\subsubsection{Analisis Pengukuran Nilai Jitter}

Jitter merupakan selisih waktu antara kedatangan paket pertama dan paket selanjutnya dalam satuan milisecond (ms). Perhitungan data jitter disini diukur melalui halaman website info.onsip.com/voip-test dan sourceforge.net/speedtest. Dari tabel tersebut dapat disimpulkan bahwa jitter tertinggi terdapat pada tahap 1 sebelum diimplementasi dengan nilai jitter sebesar $183 \mathrm{~ms}$ pada website info.onsip.com dan $6 \mathrm{~ms}$ jitter pada website sourceforget.net. Sedangkan pada tahap 2 yang sesudah diimplementasi memiliki hasil jitter sebesar $8 \mathrm{~ms}$ pada website info.onsip.com dan $3 \mathrm{~ms}$ jitter pada website sourceforget.net.

Tabel 9. Hasil pengukuran jitter

\begin{tabular}{ccc}
\hline Tahapan Analisis & Website & Jitter $(\mathbf{m s})$ \\
\hline \multirow{2}{*}{1} & info.onsip.com & 183 \\
& sourceforge.net & 6 \\
2 & info.onsip.com & 8 \\
& sourceforge.net & 3 \\
\hline
\end{tabular}

\subsubsection{Analisis Kecepatan Bandwidth}

Untuk mengukur kecepatan bandwidth digunakan 2 Web Apps melalui halaman website yaitu info.onsip.com dan sourceforge.net. Hasil pengukuran kecepatan bandwidth dapat disimpulkan bahwa terjadi peningkatan bandwidth secara signifikan pada tahap 2 sesudah diimplementasi dengan kecepatan download sebesar 45,9 Mbit/s dan upload $16.8 \mathrm{Mbit} / \mathrm{s}$ pada web apps sourceforge.net/speed-test. Dan pada web apps info.onsip.com/voip-test, mendapat nilai kecepatan download sebesar 37,0 Mbit/s dan upload 6,5 Mbit/s. Sedangkan pada tahap 1 sebelum diimplementasi mendapat nilai download sebesar 8,1 Mbit/s dan upload 3,5 Mbit/s pada web apps info.onsip.com/voip-test dan untuk web apps sourceforge.net/speed-test terdapat download $38.0 \mathrm{Mbit} / \mathrm{s}$ dan upload $11.7 \mathrm{Mbit} / \mathrm{s}$.

Tabel 10. Hasil pengukuran bandwidth

\begin{tabular}{cccc}
\hline Tahapan Analisis & Website & Download Rate (Mbit/s) & Upload Rate (Mbit/s) \\
\hline \multirow{2}{*}{1} & info.onsip.com & 8,1 & 3,5 \\
& sourceforge.net & 38,0 & 11,7 \\
2 & info.onsip.com & 37,0 & 6,5 \\
& sourceforge.net & 45,9 & 16,8 \\
\hline
\end{tabular}




\subsection{Analisis Limit Bandwidth Dengan Menggunakan Internet Download Manager (IDM)}

Untuk menganalisa batasan bandwidth yang diberikan kepada setiap user, akan digunakan software Internet Download Manager (IDM) sebagai acuan untuk mengukur Download dan Upload sebuah jaringan yang sudah dibatasi. Pengukuran dilakukan dengan 2 tahapan yaitu sebelum dan sesudah diimplementasi Limit Bandwidth dan diuji dengan mengunduh sebuah file secara bersamaan oleh 3 user menggunakan software Internet Download Manager. Hasil pengukuran Limit Bandwidth dapat disimpulkan bahwa setelah diimplementasikan limit bandwidth, jaringan internet di PT. LFC Teknologi Indonesia lebih stabil dan tidak saling tarik-menarik bandwidth antar user dengan nilai download user Samsung 103,54 KB/s, Lenovo 111,60 KB/s dan 130,95 KB/s untuk Suzuki. Sedangkan sebelum diimplementasikan Limit Bandwidth, ketiga user saling tarik-menarik bandwidth pada saat bersamaan mengunduh 1 file dengan nilai download Samsung $1051 \mathrm{~KB} / \mathrm{s}$, Lenovo 985,75 KB/s dan $1713 \mathrm{~KB} / \mathrm{s}$ untuk Suzuki.

Tabel 11. Hasil pengukuran limit bandwidth

\begin{tabular}{clrrrr}
\hline \multirow{2}{*}{ Tahap } & \multirow{2}{*}{ Parameter } & \multicolumn{1}{c}{$\begin{array}{c}\text { User } \\
\text { Samsung }\end{array}$} & User Lenovo & User Suzuki & \multicolumn{1}{c}{ Average } \\
\hline \multirow{2}{*}{1} & Download & $1051 \mathrm{~KB} / \mathrm{s}$ & $985,75 \mathrm{~KB} / \mathrm{s}$ & $1713 \mathrm{~KB} / \mathrm{s}$ & $1249,91 \mathrm{~KB} / \mathrm{s}$ \\
& Upload & $18 \mathrm{~KB} / \mathrm{s}$ & $19 \mathrm{~KB} / \mathrm{s}$ & $38 \mathrm{~KB} / \mathrm{s}$ & $25 \mathrm{~KB} / \mathrm{s}$ \\
\multirow{2}{*}{2} & Download & $103,54 \mathrm{~KB} / \mathrm{s}$ & $111,60 \mathrm{~KB} / \mathrm{s}$ & $130,95 \mathrm{~KB} / \mathrm{s}$ & $115.36 \mathrm{~KB} / \mathrm{s}$ \\
& Upload & $3,9 \mathrm{~KB} / \mathrm{s}$ & $6,2 \mathrm{~KB} / \mathrm{s}$ & $122 \mathrm{~KB} / \mathrm{s}$ & $44.0 \mathrm{~KB} / \mathrm{s}$ \\
\hline
\end{tabular}

\subsection{Analisis Load Balancing Dual WAN Atau ISP}

Pengujian Load Balancing di lakukan untuk mengetahui sistem jaringan internet yang dirancang dengan dua ISP dapat berjalan dengan normal ketika salah satu ISP putus atau down. Pengujian dilakukan dengan cara melakukan tes ping pada Command Prompt (CMD) dengan perintah "ping www.google.com $-t$ " untuk menguji apakah terdapat jeda pada saat salah satu ISP di matikan.

Perancangan Load Balancing Dual WAN dengan 2 ISP yakni ISP pertama dari Telkom dan ISP kedua dari Indosat Hotspot. ISP pertama Telkom dikoneksikan ke modem ZTE dan disambungkan ke wireless router Buffalo HP-WHR-G300N. Sedangkan untuk ISP kedua, Indosat disambungkan ke wireless router Buffalo WHR-HP-G300N melalui wireless router Asus RT-N15U dengan cara mengaktifkan hotspot dari smartphone dan dikoneksikan ke wireless router Asus RT-N15U dengan metode bridge.

Dari tabel dibawah dapat disimpulkan bahwa pada tahapan analisis 1 dengan kondisi internet terkoneksi dua ISP (Internet Service Provider), terdapat nilai maksimum ping $38 \mathrm{~ms}$ dan request timeout 0 kali dengan ISP Telkom sebagai koneksi utama. Sedangkan pada tahapan analisis 2 dengan kondisi ISP Telkom (utama) dimatikan, maka jaringan tersebut mengalami request timeout sebanyak 2 kali sebelum tersambung ke ISP Indosat (cadangan) serta mengalami perubahan ping dari maksimum 1040 ms menjadi $38 \mathrm{~ms}$. Untuk tahapan analisis 3 yaitu ISP Indosat terkoneksi dan ISP Telkom dimatikan mengalami request timeout sebanyak 2 kali dan maksimum ping dari 2063 ms menjadi 38 ms.

Tabel 12. Hasil pengukuran load balancing

\begin{tabular}{clcc}
\hline Tahapan Analisis & Kondisi Jaringan & Max Ping & Request Time Out \\
\hline 1 & Terkoneksi 2 ISP & $38 \mathrm{~ms}$ & $0 \mathrm{kali}$ \\
2 & ISP 1 (Telkom) dimatikan & $1040 \mathrm{~ms}$ & $2 \mathrm{kali}$ \\
3 & ISP 2 (Indosat) dimatikan & $38 \mathrm{~ms}$ & $2 \mathrm{kali}$ \\
\hline
\end{tabular}

\section{KESIMPULAN}

Berdasarkan hasil pengujian dan pembahasan implementasi optimalisasi jaringan internet dengan fitur Quality of Service yang diuji dengan menggunakan aplikasi NetWorx, Axence NetTools, dan Web Apps serta fitur Limit Bandwidth dan Load Balancing yang diuji dengan menggunakan aplikasi Internet Download Manager dan tes ping pada jaringan internet di PT. LFC Teknologi Indonesia, maka penelitian ini memberikan kesimpulan sebagai berikut:

a. Pemantauan traffic jaringan internet yang dilakukan di PT. LFC Teknologi Indonesia dibagi dalam 2 tahap yaitu tahap pertama merupakan pemantauan jaringan sebelum melakukan implementasi Quality of Service, Limit Bandwidth dan Load Balancing, sedangkan tahap kedua merupakan pemantauan jaringan sesudah melakukan optimalisasi. Masing-masing tahap dilakukan pemantauan jaringan dalam 2 hari. Jaringan internet tahapan kedua lebih stabil dan 
lebih cepat dibandingkan tahap pertama karena kecepatan nilai download $58.35 \mathrm{MB} / \mathrm{s}$, sedangkan pada tahap 1 nilai download $29.65 \mathrm{MB} / \mathrm{s}$.

b. Quality of Service $(Q o S)$, pada tahap pertama memiliki nilai throughput, delay, packet loss, latency dan jitter yang cukup tinggi dengan nilai throughput 4431,32 Kbit/s, delay $23 \mathrm{~ms}$, packet loss 2\%, latency $299 \mathrm{~ms}$, jitter $183 \mathrm{~ms}$. Sedangkan untuk bandwidth lebih rendah dengan download rate 38,0 Mbit/s dan upload rate 11,7 Mbit/s. Pada tahap kedua nilai throughput, delay, packet loss, latency dan jitter lebih rendah dengan nilai throughput 4281,62 Kbit/s, delay $13 \mathrm{~ms}$, packet loss 0\%, latency $243 \mathrm{~ms}$ dan jitter $8 \mathrm{~ms}$. Sedangkan untuk bandwidth lebih tinggi dengan download rate 45,9 Mbit/s dan upload rate 16,18 Mbit/s.

c. Limit Bandwidth, pada tahapan kedua lebih stabil dan bandwidth terbagi rata dengan nilai download $1 \mathrm{Mb} / \mathrm{s}$ per user. User Samsung memiliki nilai download sebesar 103,54 Kb/s, user Lenovo dengan nilai download 111,60 Kb/s dan nilai download 130,95 Kb/s untuk user Suzuki. Sedangkan untuk tahapan pertama, user Samsung memiliki nilai download $1051 \mathrm{~Kb} / \mathrm{s}$, user Lenovo dengan nilai download 985,75 Kb/s dan nilai download $1713 \mathrm{~Kb} / \mathrm{s}$ untuk user Suzuki.

d. Penerapan Load Balancing jaringan di PT. LFC Teknologi Indonesia dapat berfungsi normal dengan 3 tahapan dimana tahapan pertama terkoneksi 2 ISP dari Telkom dan Indosat dengan maksimal ping $38 \mathrm{~ms}$ dan 0 kali request time out (RTO). Tahapan kedua dengan dimatikan ISP dari Telkom, mengalami perubahan ping dari maksimal $38 \mathrm{~ms}$ menjadi $1040 \mathrm{~ms}$ dan 2 kali request time out. Perubahan ping merupakan pergantian dari koneksi ISP Telkom menjadi koneksi ISP Indosat dan dapat ditarik kesimpulan bahwa pergantian tergolong cepat dengan jeda hanya 2 kali request time out. Begitu juga dengan tahapan ketiga dimana koneksi ISP dari Indosat dimatikan, pergantian koneksi ke ISP Telkom dengan maksimal ping dari $2063 \mathrm{~ms}$ menjadi $38 \mathrm{~ms}$ dan request time out sebanyak 2 kali.

\section{DAFTAR PUSTAKA}

[1] B. Sanou, "Youth Are At The Forefront Of Internet Adoption," Itu, pp. 1-8, 2017.

[2] I. Iskandar and A. Hidayat, "Analisa Quality of Service (QoS) Jaringan Internet Kampus (Studi Kasus: UIN Suska Riau),” J. CorelIT, vol. 1, no. 2, pp. 67-76, 2015.

[3] S. Upadhyaya and G. Devi, "Characterization of QoS Based Routing Algorithms," vol. 1, no. 3, pp. 133-141, 2010.

[4] V. Mehta and N. Gupta, "Performance Analysis of QoS Parameters for Wimax Networks," Int. J. Eng. Innov. Technol., vol. 1, no. 5, pp. 105-110, 2012.

[5] S. Sarwar and D. Mahra, "Optimization of Computer Networks," vol. 2, no. 5, pp. 723-726, 2011.

[6] Rasudin, "Quality of Service (QoS) pada Jaringan Internet dengan Metode Hierarchy Token Bucket," Qual. Serv. Pada Jar. Internet Dengan Metod. Hierarchy Token Bucket, vol. 4, no. 1, 2014.

[7] A. Rahmatulloh and F. MSN, "Implementasi Load Balancing Web Server menggunakan Haproxy dan Sinkronisasi File pada Sistem Informasi Akademik Universitas Siliwangi", Jurnal Teknologi dan Sistem Informasi, vol. 3, no. 2, pp. 241-248, 2017.

[8] S. Akintoye, A. Bagula, Y. Djemaiel, and N. Bouriga, "A Survey on Storage Techniques in Cloud Computing,” Int. J. Comput. Appl., vol. 163, no. 2, pp. 22-30, 2017.

[9] A. Akbar and S. S. Wanda, "Analisa dan Perancangan Load Balancing pada Jaringan Komputer di Gedung DPR-RI Jakarta,” pp. 389-394, 2017.

[10] Sahari, "Aplikasi Load Balancing PC Mikrotik Untuk Menggabungkan Dua Kecepatan Akses Internet Dari Dua ISP," vol. 2, no. 1, pp. 15-24, 2015.

[11] F. Fitriastuti and D. P. Utomo, "Implementasi Bandwidth Management dan Firewall System Menggunakan Mikrotik OS versi 2.9.27," J. Tek., vol. 4, no. 1, pp. 1-9, 2014.

[12] K. Richmond U, K. Shade O, O. Samson O, and A. Aderonke A, "Management and Control of Bandwidth in Computer Networks," vol. 2, no. 3, pp. 342-348, 2012.

[13] A. Rahman and H. Haviluddin, "Implementation of Bandwidth Management Authentication," Int. J. Comput. Informatics, vol. 1, no. 1, pp. 1-8, 2016.

[14] S. Suryabrata, Metodologi Penelitian. Jakarta: RajaGrafindo Persada (Rajawali Perss), 2013.

[15] Sugiyono, Memahami Penelitian Kuantitatif. Bandung: Alfabeta, 2012.

[16] Sugiyono, "Metode Penelitian Manajemen," Alfabeta, p. 820, 2013. 